\title{
SLC66 Lysosomal amino acid transporters (version 2020.5) in the IUPHAR/BPS Guide to Pharmacology Database
}

\author{
Gergely Gyimesi ${ }^{1}$
}

1. Universität Bern, Switzerland

\begin{abstract}
This is a family of 5 evolutionarily related proteins. Their structural similarities suggest that they are transporters. Biochemical evidence supports transporter activity for SLC66A1 (LAAT1) and SLC66A4 (CTNS; Cystinosin). The functions of the 3 remaining members of the family are undetermined.
\end{abstract}

\section{Contents}

This is a citation summary for SLC66 Lysosomal amino acid transporters in the Guide to Pharmacology database (GtoPdb). It exists purely as an adjunct to the database to facilitate the recognition of citations to and from the database by citation analyzers. Readers will almost certainly want to visit the relevant sections of the database which are given here under database links.

GtoPdb is an expert-driven guide to pharmacological targets and the substances that act on them. GtoPdb is a reference work which is most usefully represented as an on-line database. As in any publication this work should be appropriately cited, and the papers it cites should also be recognized. This document provides a citation for the relevant parts of the database, and also provides a reference list for the research cited by those parts.

Please note that the database version for the citations given in GtoPdb are to the most recent preceding version in which the family or its subfamilies and targets were substantially changed. The links below are to the current version. If you need to consult the cited version, rather than the most recent version, please contact the GtoPdb curators.

\section{Database links}

SLC66 Lysosomal amino acid transporters

https://www.guidetopharmacology.org/GRAC/FamilyDisplayForward?familyld=1048

Transporters

solute carrier family 66 member 1

https://www.guidetopharmacology.org/GRAC/ObjectDisplayForward?objectld=3160 solute carrier family 66 member 2

https://www.guidetopharmacology.org/GRAC/ObjectDisplayForward?objectld=3161 solute carrier family 66 member 3

https://www.guidetopharmacology.org/GRAC/ObjectDisplayForward?objectld=3162 cystinosin, lysosomal cystine transporter

https://www.guidetopharmacology.org/GRAC/ObjectDisplayForward?objectld=3163 mannose-P-dolichol utilization defect 1

https://www.guidetopharmacology.org/GRAC/ObjectDisplayForward?objectld=3164

\section{References}

1. Kalatzis V, Cherqui S, Antignac C and Gasnier B. (2001) Cystinosin, the protein defective in cystinosis, is a $\mathrm{H}(+)$-driven lysosomal cystine transporter. EMBO J 20: 5940-9 [PMID:11689434]

2. Liu B, Du H, Rutkowski R, Gartner A and Wang X. (2012) LAAT-1 is the lysosomal lysine/arginine transporter that maintains amino acid homeostasis. Science 337: 351-4 [PMID:22822152]

3. Ruivo R, Bellenchi GC, Chen X, Zifarelli G, Sagné C, Debacker C, Pusch M, Supplisson S and Gasnier B. (2012) Mechanism of proton/substrate coupling in the heptahelical lysosomal transporter cystinosin. Proc Natl Acad Sci U S A 109: E210-7 [PMID:22232659] 
